\title{
Temporal Variations in Groundwater Quality with Special Reference to Irrigation in Faridkot and Muktsar Areas of Southwest Punjab, India
}

\author{
Prerna Sharma ${ }^{1}$, Madhuri S. Rishi ${ }^{2}$, Tenzin Thakur ${ }^{3}$ \\ Department of Environment Studies, Panjab University, Chandigarh-160014
}

\begin{abstract}
Punjab, known as the "bread basket of India", is a modest-sized state tucked away on the north-western border of India with huge grain surplus produced by its farmers since the green revolution, thus helping the country in its journey towards self-sufficiency in food. Yet, the agriculture in its intensive form involved high consumption of fertilizers and irrigation. Recent studies from different organizations confirmed massive concentration of chemical fertilizers and heavy metals insouth-western parts of Punjab. Faridkot and Muktsar, located in southwest of the state, are two agriculture dominated districts of Southwest Punjab.This paper highlights temporal variations of groundwater quality and comparison on its suitability for irrigation purposes in these two districts. In both the districts, total hardness and sodium adsorption ratio was indicative of the unsuitability of groundwater for irrigation purposes. The water samples in the study area showed appreciable risein electrical conductivity indicating high salinity, especially in Muktsar district. In order to use the water resources judiciously and maintain the agricultural productivity, there is a need for groundwater management, which will lead to sustainable development in Faridkot and Muktsar.
\end{abstract}

Keywords: Groundwater, Irrigation, Salinity, Sodium adsorption ratio, Sustainable Development.

\section{Introduction}

On planet Earth, water is basic and most important resource for the sustenance of life. Groundwater, a significant natural resource, has become increasingly popular because of the relative ease and flexibility with which it can be tapped. It is the most extracted natural resource in the world providingfor both drinking and agricultural activities like irrigation.Globally, irrigation accounts for more than $70 \%$ oftotal water withdrawals and for more than $90 \%$ oftotal consumptive water use ${ }^{[1][2][3]}$ The use of groundwater of marginal and poor quality without proper mixing with canal water may degrade the soils, especially at the tail end of the canal system ${ }^{[4]}$.

The south-western part of Punjab in India is a region with predominantly agrigarian culture, and irrigation has been the main stay of their economy, prosperity and development. Therefore, the main occupation of majority of the population is agriculture and the main sources of irrigation are tubewells, wells, pumping sets and canals. The large scale extraction of groundwater can be attributed to the 'Green Revolution'. Irrigation accounts for 69 percent of all global fresh water use, while industry and domestic uses consume 23 percent and 8 percent respectively ${ }^{[5]}$.

During the last decade, implementation of agricultural practices in the state has become increasingly environmentally unsustainable, which has taken its toll on the groundwater of the region. The groundwater is facing problems of depletion of water table, saltwater encroachment, drying of aquifers, groundwater pollution, water logging and salinity and these are major consequences of overexploitation and intensive irrigation ${ }^{[6]}$.Two districts of southwest Punjab namely Faridkot and Muktsar, which are very distinct in their sub-surface lithology and soil type as well as the groundwater scenario (Table 1) were thereby chosen to assess the temporal variations of groundwater quality and diagnose the hazards of groundwater in relation to its suitability for irrigation purpose due to their varying lithological units and aquifer disposition. Thus, the proposed study will not only help in devising suitable strategies to protect water regime of southwest tracts of Punjab but can also give directions for the protection of those areas that have not yet been invaded for groundwater mining.

\section{Location of Study Area}

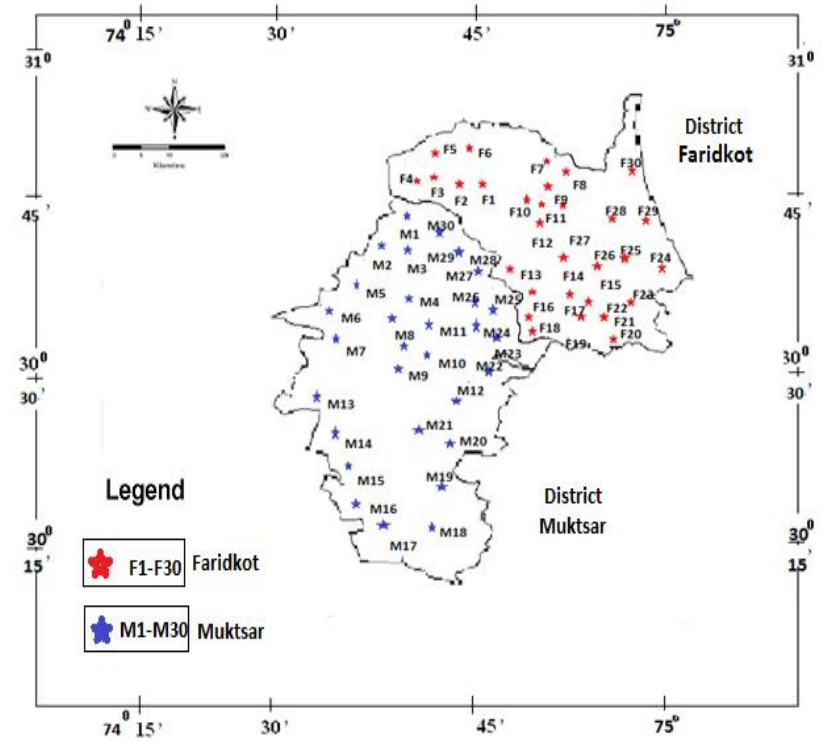

Figure 1: Map showing sampling locations of the study area 


\section{International Journal of Science and Research (IJSR) \\ ISSN (Online): 2319-7064}

Index Copernicus Value (2015): 78.96 | Impact Factor (2015): 6.391

Table1: Comparative Status of Two Districts at a Glance

\begin{tabular}{|c|c|c|}
\hline $\begin{array}{l}\text { Particulars } \\
\end{array}$ & Faridkot & Muktsar \\
\hline \multicolumn{3}{|l|}{ GENERAL INFORMATION } \\
\hline i)Geographical Area $\left(\mathrm{km}^{2}\right)$ & 1468.75 & 2630 \\
\hline $\begin{array}{l}\text { ii)Administrative Division } \\
\text { No. of Panchayats/villages }\end{array}$ & 171 & 235 \\
\hline $\begin{array}{l}\text { iii)Population(as per } 2001 \text { census) } \\
\text { (as per } 2011 \text { census) } \\
\text { (\% Increase) }\end{array}$ & $\begin{array}{c}550892 \\
618008 \\
10.86 \\
\end{array}$ & $\begin{array}{c}7,77,493 \\
9,02,702 \\
13.87 \\
\end{array}$ \\
\hline iv)Avg. annual rainfall(mm) & 449 & 430.7 \\
\hline \multicolumn{3}{|l|}{ GEOMORPHOLOGY } \\
\hline Major physiographic units & Alluvium & Alluvium \\
\hline Major Drainage & Sutlej & Sutlej \\
\hline \multicolumn{3}{|l|}{ LAND USE $\left(\mathrm{km}^{2}\right)$} \\
\hline a.Forest area & 20.04 & 20 \\
\hline b.Net area sown & 1258.51 & 2260 \\
\hline c.Cultivable area & 860 & 2210 \\
\hline MAJOR SOIL TYPES & Sandy loam & Sierozem soil and desert soil \\
\hline AREA UNDER PRINCIPAL CROPS (Ha) & $\begin{array}{l}\text { 92300(kharif) } \\
86650 \text { (rabi) }\end{array}$ & $\begin{array}{c}\text { Rice-770 } \\
\text { Wheat-2000 Cotton-1170 } \\
\end{array}$ \\
\hline PREDOMINANT GEOLOGICAL FORMATIONS & Alluvium & Alluvium \\
\hline $\begin{array}{l}\text { HYDROGEOLOGY } \\
\text { Major Water bearing formations } \\
\text { Pre-monsoon depth to Water Level } \\
\text { Post-monsoon depth to Water Level } \\
\text { Long term water level trend in } 10 \text { years in } \mathrm{m} / \mathrm{yr} \text {. }\end{array}$ & $\begin{array}{c}\text { Sand, gravel } \\
2.8-14.10 \mathrm{mbgl} \\
1.85-15.20 \mathrm{mbgl} \\
0.10-0.70 \mathrm{mbgl} \\
\text { Average- } 0.40 \mathrm{~m} / \text { year } \\
\end{array}$ & $\begin{array}{c}\text { Sand } \\
1.65-6.43 \mathrm{mbgl} \\
1.49-6.63 \mathrm{mbgl} \\
-1.16-3.87 \mathrm{mbgl}\end{array}$ \\
\hline $\begin{array}{l}\text { DYNAMIC GROUNDWATER RESOURCES (mcm) } \\
\text { Annual Replenishable groundwater resources } \\
\text { Net Annual groundwater Draft } \\
\text { Projected demand for domestic and industrial uses upto } 2025 \\
\text { Stage of groundwater development }(\%)\end{array}$ & $\begin{array}{c}610.61 \\
975.46 \\
26.60 \\
106 \\
\end{array}$ & $\begin{array}{c}779.14 \\
540.85 \\
1.60 \\
74 \\
\end{array}$ \\
\hline Groundwater Problems and Issues & Salinity and decline in water table. & Salinity and water logging. \\
\hline
\end{tabular}

\section{Material and Method}

A systematic and periodical sampling was conducted to collect the water samples from tubewells and handpumps during pre and post monsoon in the area for evaluation.Water samples were collected and analyzed, hydrogeological and statistical data was collected from state Govt. agencies to supplement the field investigations. During sampling, record of location, temperature, depth and special characteristics was maintained. Thirty groundwatersamples each were collected from both the districts in April (pre-monsoon) and same locations were again sampled in September (post-monsoon) to evaluate seasonal variations (Fig. 1). Water samples were collected in clean polyethylene bottles. At the time of sampling, bottles were thoroughly rinsed two to three times with groundwater to be sampled. To remove groundwater stored in the well,in the case of borewells and handpumps, the water samples were collected after pumping for $10 \mathrm{~min}$.

A scientific, well tested and technically sound methodology was followed for performing the water analysis. $\mathrm{pH}, \mathrm{EC}$ and TDS were measured Electrometrically using $\mathrm{pH}$ meter and conductivity meter.
Carbonates, Bicarbonates and Total Hardness were measured using EDTA (Ethylene diaminetetraacetic acid) Titrimetric method, using ammoniabuffer solution.Measurement of Chloride was done using Argenotometric method, Sodium and Potassium using Flame photometric method and Phosphate and Nitrate by UV Spectrophotometric method.

Sulphate and Fluoride were determined using UV Spectrophotometric and SPADNS method respectively.

\section{Suitability of Groundwater for Irrigation Based on SAR and RSC}

The suitability of water for irrigation depends upon the effect of chemical constituents in water on plant growth and soil. The important parameters are salinity, relative proportion of sodium to calcium and magnesium (SAR), relative proportion of bicarbonate to calcium and magnesium (RSC) which was calculated using table 2 and 3 for Faridkot and Muktsar respectively. The majority of groundwater in the area has high salt contents and high RSC, which poses following type of hazards and rendered many areas unproductive. 


\section{International Journal of Science and Research (IJSR) \\ ISSN (Online): 2319-7064}

Index Copernicus Value (2015): 78.96 | Impact Factor (2015): 6.391

Table 2: Summary statistics of chemical constituents of groundwater in Faridkot district

\begin{tabular}{|c|c|c|c|c|c|c|c|c|c|c|c|}
\hline \multirow{2}{*}{ Parameter } & \multirow{2}{*}{ Unit } & \multicolumn{2}{|c|}{ Minimum } & \multicolumn{2}{|c|}{ Maximum } & \multicolumn{2}{|c|}{ Average } & \multicolumn{2}{|c|}{ Median } & \multicolumn{2}{|c|}{ Std deviation } \\
\hline & & PRM & POM & PRM & $\mathrm{POM}$ & PRM & POM & PRM & POM & PRM & POM \\
\hline $\mathrm{pH}$ & - & 7.2 & 6.9 & $\begin{array}{l}7.7 \\
\end{array}$ & 8.3 & 7.5 & 7.6 & 7.5 & 7.6 & 0.2 & 0.4 \\
\hline TDS & $\mathrm{mg} / \mathrm{l}$ & 610.0 & 650.0 & 1890.0 & 1984.0 & 926.4 & 987.4 & 800.0 & 907.5 & 299.3 & 322.7 \\
\hline $\mathrm{EC}$ & $\mu \mathrm{S} / \mathrm{cm}$ & 780.0 & 1142.0 & 4568.0 & 5236.0 & 1760.2 & 1962.8 & 1419.5 & 1527.0 & 894.3 & 1005.9 \\
\hline $\mathrm{Na}^{+}$ & $\mathrm{mg} / \mathrm{l}$ & 1.9 & 2.0 & 1075.0 & 1125.0 & 176.7 & 190.3 & 100.1 & 106.8 & 252.9 & 263.6 \\
\hline $\mathrm{K}^{+}$ & $\mathrm{mg} / \mathrm{l}$ & 3.0 & 2.1 & 108.0 & 106.0 & 22.5 & 19.9 & 10.3 & 9.1 & 24.2 & 22.7 \\
\hline $\mathrm{Ca}^{2+}$ & $\mathrm{mg} / \mathrm{l}$ & 25.2 & 16.8 & 103.4 & 90.8 & 41.9 & 34.9 & 37.8 & 31.9 & 19.7 & 18.4 \\
\hline $\mathrm{Mg}^{2+}$ & $\mathrm{mg} / \mathrm{l}$ & 32.6 & 33.2 & 142.0 & 143.5 & 82.9 & 80.1 & 80.7 & 76.8 & 31.1 & 31.4 \\
\hline $\mathrm{HCO}_{3}^{-}$ & $\mathrm{mg} / \mathrm{l}$ & 105.0 & 150.0 & 945.0 & 1090.0 & 415.2 & 475.6 & 382.5 & 447.5 & 161.4 & 174.9 \\
\hline $\mathrm{Cl}^{-}$ & $\mathrm{mg} / \mathrm{l}$ & 17.7 & 14.2 & 417.5 & 463.6 & 163.2 & 184.8 & 139.5 & 159.4 & 90.7 & 99.8 \\
\hline $\mathrm{SO}_{4}^{2}$ & $\mathrm{mg} / \mathrm{l}$ & 40.2 & 46.7 & 894.1 & 1051.6 & 215.3 & 252.9 & 196.8 & 225.3 & 155.6 & 177.9 \\
\hline $\mathrm{PO}_{4}^{3-}$ & $\mathrm{mg} / \mathrm{l}$ & 0.1 & 0.0 & 0.4 & 0.3 & 0.2 & 0.1 & 0.2 & 0.1 & 0.1 & 0.1 \\
\hline $\mathrm{NO}_{3}^{-}$ & $\mathrm{mg} / \mathrm{l}$ & 0.1 & 0.2 & 127.4 & 125.2 & 21.3 & 22.6 & 12.7 & 13.6 & 30.7 & 31.3 \\
\hline $\mathrm{F}^{-}$ & $\mathrm{mg} / \mathrm{l}$ & 0.1 & 0.0 & 4.3 & 4.2 & 1.2 & 1.0 & 0.8 & 0.7 & 1.1 & 1.0 \\
\hline $\mathrm{TH}$ & $\mathrm{mg} / \mathrm{l}$ & 224.0 & 200.0 & 680.0 & 676.0 & 439.3 & 411.6 & 436.0 & 394.0 & 138.2 & 140.0 \\
\hline $\mathrm{TH}$ as $\mathrm{CaCO}_{3}$ & $\mathrm{mg} / \mathrm{l}$ & 60.0 & 40.0 & 246.0 & 216.0 & 99.7 & 83.1 & 90.0 & 76.0 & 46.8 & 43.7 \\
\hline
\end{tabular}

*PRM- Pre monsoon POM- Post monsoon

Table 3: Summary statistics of chemical constituents of groundwater in Muktsar district

\begin{tabular}{|c|c|c|c|c|c|c|c|c|c|c|c|}
\hline \multirow{2}{*}{ Parameter } & \multirow{2}{*}{ Units } & \multicolumn{2}{c|}{ Minimum } & \multicolumn{2}{c|}{ Maximum } & \multicolumn{2}{c|}{ Average } & \multicolumn{2}{c|}{ Median } & \multicolumn{2}{c|}{ Std deviation } \\
\cline { 3 - 12 } & & PRE & POM & PRE & POM & PRE & POM & PRE & POM & PRE & POM \\
\hline $\mathrm{pH}$ & - & 6.7 & 7.0 & 8.1 & 8.2 & 7.5 & 7.8 & 7.6 & 7.9 & 0.4 & 0.3 \\
\hline $\mathrm{TDS}$ & $\mathrm{mg} / \mathrm{l}$ & 150.0 & 186.0 & 2500.0 & 2765.0 & 1082.0 & 1163.8 & 780.0 & 860.0 & 692.4 & 742.6 \\
\hline $\mathrm{EC}$ & $\mu \mathrm{S} / \mathrm{cm}$ & 400.0 & 484.0 & 6998.0 & 7780.0 & 2566.4 & 2976.0 & 1690.0 & 1850.0 & 2014.6 & 2355.0 \\
\hline $\mathrm{Na}^{+}$ & $\mathrm{mg} / 1$ & 3.8 & 8.0 & 887.0 & 990.0 & 182.9 & 209.8 & 50.7 & 55.0 & 268.8 & 297.8 \\
\hline $\mathrm{K}^{+}$ & $\mathrm{mg} / \mathrm{l}$ & 2.4 & 1.9 & 869.0 & 865.0 & 49.9 & 41.0 & 7.9 & 7.0 & 154.6 & 157.7 \\
\hline $\mathrm{Ca}^{2+}$ & $\mathrm{mg} / \mathrm{l}$ & 17.6 & 17.6 & 308.6 & 209.6 & 80.4 & 68.2 & 73.1 & 58.8 & 59.7 & 54.2 \\
\hline $\mathrm{Mg}^{2+}$ & $\mathrm{mg} / 1$ & 0.9 & 1.0 & 193.2 & 171.7 & 46.5 & 46.9 & 24.4 & 29.2 & 57.1 & 57.5 \\
\hline $\mathrm{HCO}_{3}^{-}$ & $\mathrm{mg} / 1$ & 105.0 & 150.0 & 1120.0 & 1285.0 & 389.5 & 426.2 & 360.0 & 385.0 & 214.0 & 241.9 \\
\hline $\mathrm{Cl}^{-}$ & $\mathrm{mg} / 1$ & 58.2 & 69.5 & 858.3 & 1039.4 & 180.7 & 203.7 & 132.7 & 142.7 & 160.1 & 193.7 \\
\hline $\mathrm{SO}^{2}{ }_{4}$ & $\mathrm{mg} / 1$ & 11.3 & 11.4 & 720.4 & 790.2 & 100.8 & 112.9 & 40.2 & 43.5 & 169.5 & 186.0 \\
\hline $\mathrm{PO}^{3-}{ }_{4}$ & $\mathrm{mg} / 1$ & 0.0 & 0.0 & 0.5 & 0.1 & 0.2 & 0.1 & 0.2 & 0.1 & 0.1 & 0.0 \\
\hline $\mathrm{NO}_{3}^{-}$ & $\mathrm{mg} / 1$ & 1.6 & 1.7 & 596.8 & 599.4 & 68.6 & 71.3 & 22.2 & 26.4 & 137.8 & 142.1 \\
\hline $\mathrm{F}^{-}$ & $\mathrm{mg} / 1$ & 0.1 & 0.1 & 13.6 & 13.8 & 1.1 & 1.1 & 0.6 & 0.4 & 2.5 & 2.3 \\
\hline $\mathrm{TH}$ & $\mathrm{mg} / 1$ & 120.0 & 108.0 & 864.0 & 830.0 & 382.1 & 354.6 & 268.0 & 244.0 & 234.5 & 244.0 \\
\hline $\mathrm{TH}$ as $\mathrm{CaCO}_{3}$ & $\mathrm{mg} / 1$ & 42.0 & 42.0 & 734.0 & 641.2 & 191.3 & 162.2 & 174.0 & 140.0 & 142.0 & 129.0 \\
\hline
\end{tabular}

*PRM- Pre monsoon POM- Post monsoon

Table 4: Statistical analysis of groundwater samples with respect to agricultural practices in Faridkot district

\begin{tabular}{|c|l|c|c|c|c|c|c|}
\hline $\begin{array}{c}\text { Sample } \\
\text { No. }\end{array}$ & \multicolumn{1}{|c|}{ Location } & $\%$ Na (PRM) & $\begin{array}{c}\text { \%Na } \\
\text { (POM) }\end{array}$ & $\begin{array}{c}\text { SAR } \\
\text { (PRM) }\end{array}$ & $\begin{array}{c}\text { SAR } \\
\text { (POM) }\end{array}$ & $\begin{array}{c}\text { RSC } \\
\text { (PRM) }\end{array}$ & $\begin{array}{c}\text { RSC } \\
\text { (POM) }\end{array}$ \\
\hline F1 & Mehmuana & 20.09 & 17.00 & 0.01 & 0.10 & -3.83 & -2.62 \\
\hline F2 & MachakiKalan & 21.26 & 23.76 & 0.70 & 0.93 & -4.76 & -2.32 \\
\hline F3 & KauniPind & 10.82 & 12.54 & 0.42 & 0.52 & -4.34 & -3.65 \\
\hline F4 & Sadiq & 5.84 & 12.79 & 0.13 & 0.43 & 0.47 & 2.00 \\
\hline F5 & Ghugiana & 16.64 & 23.59 & 0.51 & 0.84 & -2.74 & 2.78 \\
\hline F6 & DhilwanKhurd & 21.61 & 11.33 & 0.80 & 0.32 & -3.34 & -2.09 \\
\hline F7 & BhagsinghWala & 38.84 & 43.07 & 2.06 & 2.30 & -0.01 & 2.31 \\
\hline F8 & Chandbaja & 59.45 & 72.81 & 4.12 & 8.32 & 1.42 & 3.14 \\
\hline F9 & Moranwali & 28.01 & 5.04 & 1.25 & 0.05 & 0.15 & 2.28 \\
\hline F10 & Kater & 45.59 & 47.58 & 3.81 & 3.95 & 4.46 & 7.62 \\
\hline F11 & Tehna & 42.97 & 45.01 & 3.46 & 3.67 & -5.06 & -4.27 \\
\hline F12 & Chahal & 79.05 & 79.84 & 18.68 & 19.61 & -6.30 & -4.93 \\
\hline F13 & Dhudhi & 28.43 & 32.45 & 1.57 & 1.82 & -1.93 & -0.71 \\
\hline F14 & Faridkot & 44.18 & 47.25 & 3.57 & 3.97 & -4.38 & -1.93 \\
\hline F15 & Kotkapura & 23.89 & 10.20 & 1.17 & 0.39 & -2.07 & -1.07 \\
\hline F16 & DhilwanKalan & 77.60 & 79.33 & 10.32 & 11.25 & 0.68 & 1.22 \\
\hline F17 & Matta & 57.72 & 58.89 & 5.68 & 5.92 & -6.80 & -5.67 \\
\hline F18 & Bargari & 67.05 & 69.62 & 6.62 & 7.12 & -0.16 & 0.86 \\
\hline F19 & Ramuwala & 24.55 & 26.14 & 1.53 & 1.66 & -8.30 & -7.31 \\
\hline F20 & Thara & 34.74 & 37.98 & 2.34 & 2.67 & -5.35 & -4.48 \\
\hline F21 & Maur & 39.61 & 41.21 & 2.79 & 2.97 & -5.52 & -4.22 \\
\hline F22 & Karirwali & 90.52 & 91.7 & 28.19 & 31.11 & 4.70 & 6.25 \\
\hline
\end{tabular}

Volume 6 Issue 1, January 2017 
International Journal of Science and Research (IJSR)

ISSN (Online): 2319-7064

Index Copernicus Value (2015): 78.96 | Impact Factor (2015): 6.391

\begin{tabular}{|l|l|c|c|c|c|c|c|}
\hline F23 & Ramgarh & 50.72 & 56.11 & 2.84 & 3.32 & 4.79 & 6.35 \\
\hline F24 & Jaitu & 6.63 & 9.59 & 0.26 & 0.39 & -3.66 & -1.81 \\
\hline F25 & Fatehgarh & 8.01 & 11.84 & 0.24 & 0.43 & -3.05 & -2.20 \\
\hline F26 & Chand Bhan & 10.68 & 15.67 & 0.28 & 0.54 & -4.01 & -2.98 \\
\hline F27 & Ramiana & 27.77 & 52.01 & 1.54 & 4.13 & 0.04 & 2.14 \\
\hline F28 & Khachran & 17.98 & 21.07 & 0.86 & 1.03 & -0.53 & 0.70 \\
\hline F29 & Madhak & 50.78 & 52.48 & 4.19 & 4.45 & -3.12 & -2.65 \\
\hline F30 & Surghuri & 29.85 & 31.78 & 1.80 & 1.93 & -5.44 & -4.55 \\
\hline
\end{tabular}

*PRM- Pre monsoon POM- Post monsoon

Table 5: Statistical analysis of groundwater samples with respect to agricultural practices in Muktsar district

\begin{tabular}{|c|c|c|c|c|c|c|c|}
\hline Sample & Location & $\begin{array}{c}\% \mathrm{Na} \\
(\mathrm{PRM})\end{array}$ & $\begin{array}{c}\% \mathrm{Na} \\
(\mathrm{POM})\end{array}$ & $\begin{array}{c}\text { SAR } \\
(\mathrm{PRM})\end{array}$ & $\begin{array}{c}\text { SAR } \\
(\mathrm{POM})\end{array}$ & $\begin{array}{c}\text { RSC } \\
(\mathrm{PRM})\end{array}$ & $\begin{array}{c}\mathrm{RSC} \\
(\mathrm{POM})\end{array}$ \\
\hline M1 & Dohak & 14.61 & 16.91 & 0.52 & 0.65 & -4.08 & -2.87 \\
\hline M2 & Gulabewala & 12.70 & 14.40 & 0.54 & 0.67 & -11.49 & -10.25 \\
\hline M3 & Akalgarh & 8.15 & 9.12 & 0.46 & 0.53 & -13.64 & -12.94 \\
\hline M4 & Barirwala & 8.22 & 11.99 & 0.12 & 0.26 & -1.67 & -1.13 \\
\hline M5 & Udekaran & 33.52 & 38.05 & 1.29 & 1.51 & -1.29 & -0.71 \\
\hline M6 & Haraj & 41.85 & 45.98 & 1.77 & 2.05 & 0.46 & 0.99 \\
\hline M7 & Bhuttiwala & 15.39 & 17.17 & 0.88 & 1.01 & -6.69 & -6.61 \\
\hline M8 & Bhullar & 7.71 & 10.32 & 0.30 & 0.41 & -10.64 & -7.8 \\
\hline M9 & Rupana & 61.30 & 66.23 & 3.98 & 4.62 & 2.27 & 2.77 \\
\hline M10 & Bham & 29.86 & 37.28 & 1.15 & 1.45 & 2.26 & 4.02 \\
\hline M11 & Chakduhewala & 14.69 & 15.22 & 0.82 & 0.85 & -8.88 & -8.18 \\
\hline M12 & Sotha & 64.78 & 68.98 & 4.04 & 4.62 & 15.15 & 18.13 \\
\hline M13 & Doda & 17.51 & 18.94 & 0.91 & 0.98 & -7.64 & -6.24 \\
\hline M14 & Mehrajwala & 10.39 & 11.55 & 0.66 & 0.74 & -11.09 & -10.06 \\
\hline M15 & Giljewala & 52.50 & 54.97 & 2.37 & 2.51 & 2.71 & 3.29 \\
\hline M16 & Samagh & 37.71 & 40.07 & 1.67 & 1.79 & 3.14 & 4.03 \\
\hline M17 & Muktsar & 24.88 & 32.68 & 0.88 & 1.23 & -0.51 & 0.34 \\
\hline M18 & Aulakh & 87.90 & 89.10 & 23.65 & 25.75 & 1.56 & 2.3 \\
\hline M19 & Midda & 9.11 & 14.31 & 0.40 & 0.74 & -3.24 & -2.33 \\
\hline M20 & Ghagga & 22.58 & 25.46 & 0.75 & 0.92 & -1.32 & -0.19 \\
\hline M21 & Their & 26.85 & 30.64 & 0.89 & 1.04 & 4.67 & 5.57 \\
\hline M22 & Husner & 16.61 & 24.08 & 0.69 & 1.10 & 0.37 & 1.48 \\
\hline M23 & Malout & 71.28 & 82.76 & 7.73 & 13.77 & 1.68 & 2.97 \\
\hline M24 & Qabarwala & 72.69 & 82.69 & 8.90 & 14.94 & 0.35 & 1.06 \\
\hline M25 & Lambi & 90.77 & 92.09 & 25.95 & 30.42 & -0.95 & -0.57 \\
\hline M26 & Kuttianwali & 79.23 & 82.08 & 13.81 & 16.29 & 4.08 & 7.82 \\
\hline M27 & Punjawa & 86.78 & 89.59 & 20.73 & 24.16 & -1.25 & 1.73 \\
\hline M28 & Bhittiwala & 61.43 & 62.77 & 8.20 & 8.62 & -7.26 & -6.53 \\
\hline M29 & Middikheri & 26.76 & 33.05 & 1.16 & 1.51 & -0.50 & 0.37 \\
\hline M30 & Gaggar & 25.96 & 29.91 & 0.87 & 1.05 & -0.25 & 0.39 \\
\hline
\end{tabular}

*PRM- Pre monsoon POM- Post monsoon

\section{Salinity Hazard}

The analytical data plotted on US salinity diagram ${ }^{[7]}$ shows that in Faridkot district, the groundwater for irrigation purposes is of both C3S1 and C4S1 type indicating that water in shallow aquifer is of high salinity and low sodium and very high salinity and low sodium hazard characteristic (Fig.2) similarly in district Muktsar, water samples fall almost in equal proportion in $\mathrm{C} 3 \mathrm{~S} 1$ and $\mathrm{C} 4 \mathrm{~S} 1$ fields which is suitable for plants which have good salt tolerance but restricts its suitability for irrigation,especially in soils with restricted drainag ${ }^{[8][9]}$ (Fig.4). Some of the samples in both the districts fall in C4S4 field indicating very high salinity and high sodium water thus enhancing the danger of exchangeable sodium.Both the areas need special attention as far as irrigation is concerned.

\section{Sodicity Hazard}

Around 6.6\% samples of Faridkot fall in unsuitable category (Fig.2) comparatively $40 \%$ samples of Muktsar fall in unsafe category of water class in both the seasons using the Wilcox diagram in (Fig. 3$)^{[10]}$. The high concentration of sodium reduces the permeability for $\mathrm{Ca}^{2+}$ and $\mathrm{Mg}^{2+}$ resulting in poor drainage (Kumar et al. 2007). This may also attribute to water logging condition. 


\section{International Journal of Science and Research (IJSR) \\ ISSN (Online): 2319-7064}

Index Copernicus Value (2015): 78.96 | Impact Factor (2015): 6.391
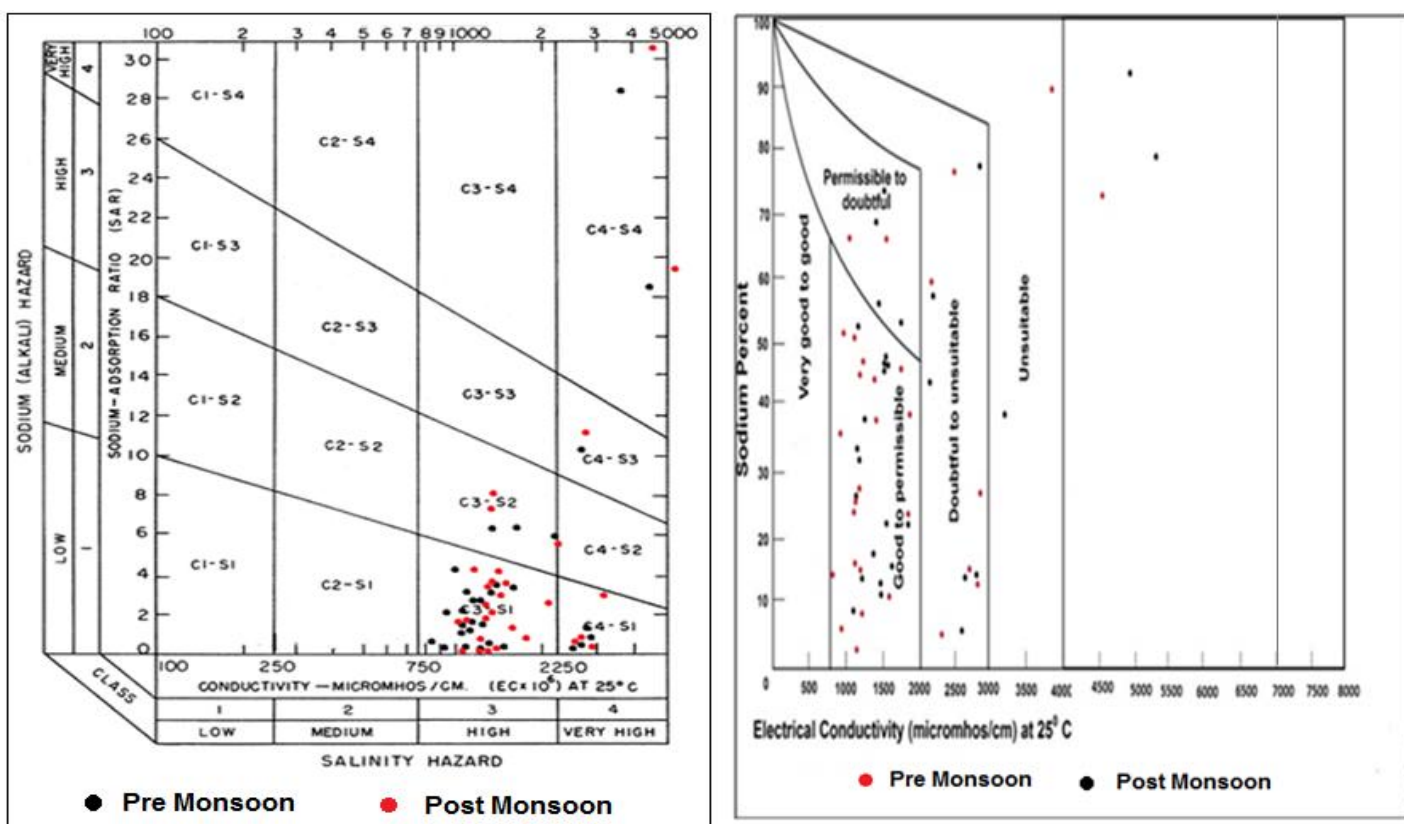

Figure 2: USSL (1954), Wilcox (1955) to show the suitability of groundwater in Faridkot for Irrigation
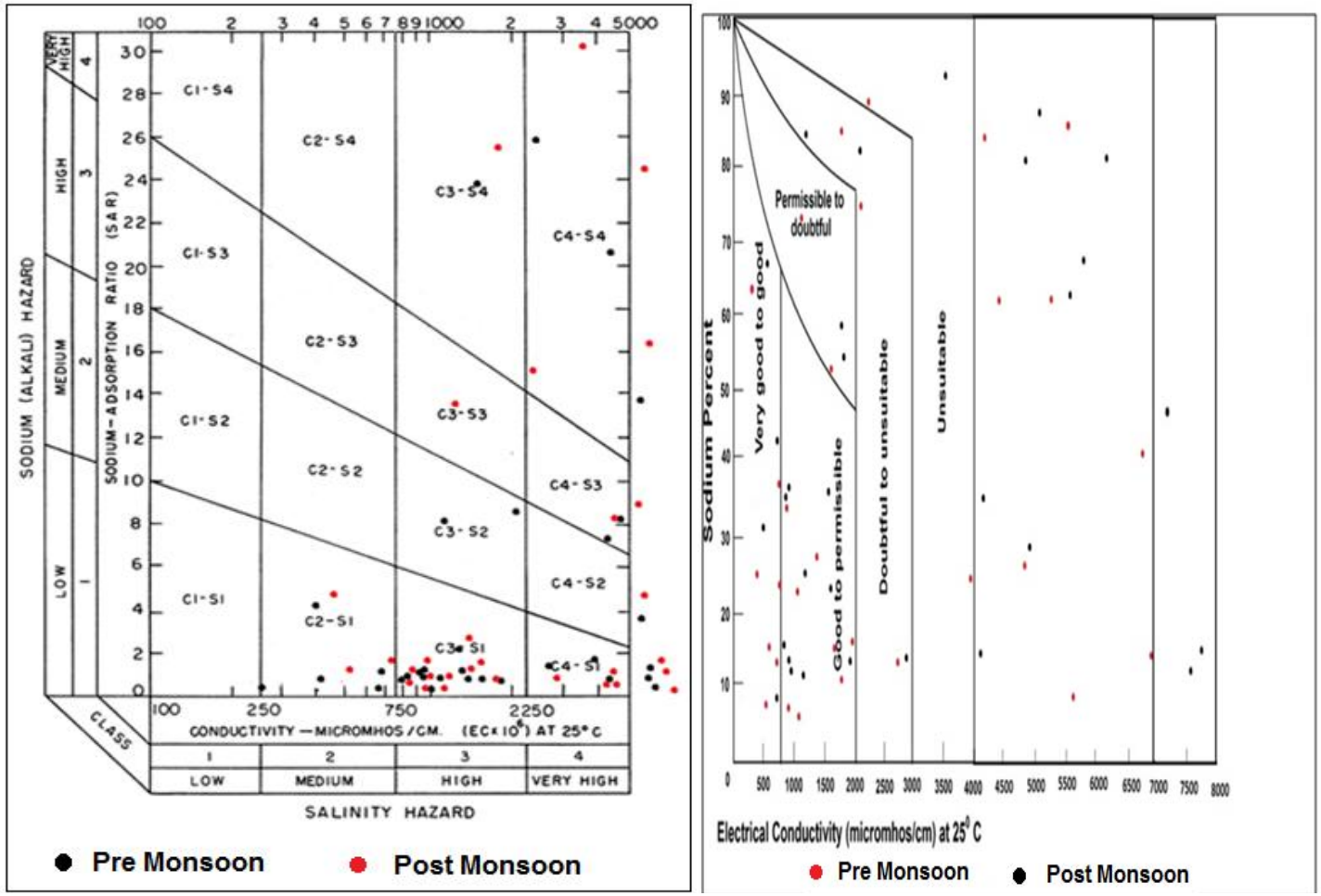

Figure 3: USSL (1954), Wilcox (1955) to show the suitability of groundwater in Muktsar for Irrigation

Suitability of Groundwater for Irrigation Based on TH (as $\mathrm{CaCO}_{3}$ ) and $\mathrm{EC}$

Total Hardness results from the presence of divalent metallic cations of which calcium and magnesium are the most abundant ${ }^{[11]}$. Table 6(a) and 6(b) shows how various natural and anthropogenic factors affect the individual ion concentrations in the two districts affecting the agriculture and irrigation.

\section{Alkalinity Hazard}

Faridkot, groundwater occurring in the shallow aquifer is saline except in some places where groundwater is fresh which is due to occurrence of fresh water lenses created by return seepage and canal seepage, 10\% samples fall in Hard water category during both pre-monsoon and post monsoon season (Table 6(a)) whereas in Muktsar46.6\% samples in pre monsoon and $33.3 \%$ samples in post monsoon fall in Hard water category. In district Muktsar $10 \%$ samples in premonsoon and $13.3 \%$ in post monsoon season fall in very hard water category. The natural cause is the presence of soil minerals producing sodium carbonate $\left(\mathrm{Na}_{2} \mathrm{CO}_{3}\right)$ and sodium bicarbonate $\left(\mathrm{NaHCO}_{3}\right)$ upon weathering. The water thus has objectionable taste and also very high conductivity values. The values are increasing in post-monsoon which indicates leaching of agricultural fertilizers and chemicals with rainwater to the groundwater ${ }^{[12]}$. The basic difference between rainwater and irrigation water is that the former is practically free from salts, while irrigation water contains

\section{Volume 6 Issue 1, January 2017




\section{International Journal of Science and Research (IJSR) \\ ISSN (Online): 2319-7064 \\ Index Copernicus Value (2015): 78.96 | Impact Factor (2015): 6.391}

varying amounts of salts in varying degrees depending on its source. This means with every irrigation a certain amount of salts are added to the soil. Table 6(b) shows that the shallow groundwater was brackish in about $23.3 \%$ samples in pre monsoon and $20 \%$ samples in post monsoon and saline in $3.3 \%$ samples in pre monsoon and $6.6 \%$ samples in post monsoon in district Faridkot. In Muktsar, 13.3\% samples in pre monsoon and $10 \%$ samples in post monsoon fall in brackish category and $33.3 \%$ in pre monsoon and $36.6 \%$ samples in post monsoon are saline.All the villages with high salinity falls under water logged areas in Muktsar block. Sodic soils present particular challenges because they tend to have very poor structure which limits or prevents water infiltration and drainage ${ }^{[13]}$.In addition to mineral weathering, salts are also deposited via dust and precipitation. In dry regions salts may accumulate, leading to naturally saline soils [8][9]. Figure 4 and 5 shows the distribution of total hardness as $\mathrm{CaCO}_{3}$ in the groundwater of district Faridkot and Muktsar respectively.

Table 6(a): Based on Total Hardness as $\mathrm{CaCO}_{3}$

\begin{tabular}{|c|c|c|c|c|c|}
\hline $\begin{array}{c}\mathrm{TH} \\
\text { asCaCO } \\
(\mathrm{mg} / \mathrm{l})\end{array}$ & \multirow{2}{*}{ Water Class } & \multicolumn{2}{c|}{$\begin{array}{c}\text { \% of Faridkot } \\
\text { Samples }\end{array}$} & \multicolumn{2}{c|}{$\begin{array}{c}\text { \% of Muktsar } \\
\text { Samples }\end{array}$} \\
\cline { 3 - 6 } & & PRE & POM & PRE & POM \\
\hline$>75$ & Soft & $23.3(7)$ & $46.6(14)$ & $13.3(4)$ & $20(6)$ \\
\hline $75-150$ & Moderately Hard & $70(20)$ & $43.3(13)$ & $30(9)$ & $33.3(10)$ \\
\hline $150-300$ & Hard & $10(3)$ & $10(3)$ & $46.6(14)$ & $33.3(10)$ \\
\hline$>300$ & Very Hard & 0 & 0 & $10(3)$ & $13.33(4)$ \\
\hline
\end{tabular}

*PRE- Pre monsoon, POM- Post monsoon (Source: Sawyer and McCartly, 1967)

(Figures in parenthesis are number of samples in the particular categories of degree of problem)

Table 6(b): Based on EC

\begin{tabular}{|c|c|c|c|c|c|}
\hline \multirow{2}{*}{$\begin{array}{c}\text { EC } \\
\mu \mathrm{S} / \mathrm{cm})\end{array}$} & \multirow{2}{*}{ Water Class } & \multicolumn{2}{|c|}{$\begin{array}{c}\text { \% of Faridkot } \\
\text { Samples }\end{array}$} & \multicolumn{2}{c|}{$\begin{array}{c}\text { \% of Muktsar } \\
\text { Samples }\end{array}$} \\
\cline { 3 - 6 } & & PRE & POM & PRE & POM \\
\hline $0-2000$ & Fresh & $73.3(22)$ & $73.3(22)$ & $53.3(16)$ & $53.3(16)$ \\
\hline $2000-4000$ & Brackish & $23.3(7)$ & $20(6)$ & $13.3(4)$ & $10(3)$ \\
\hline$>4000$ & Saline & $3.3(1)$ & $6.6(2)$ & $33.3(10)$ & $36.6(11)$ \\
\hline
\end{tabular}

*PRE- Pre monsoon, POM- Post monsoon

(Figures in parenthesis are number of samples in the particular categories of degree of problem)
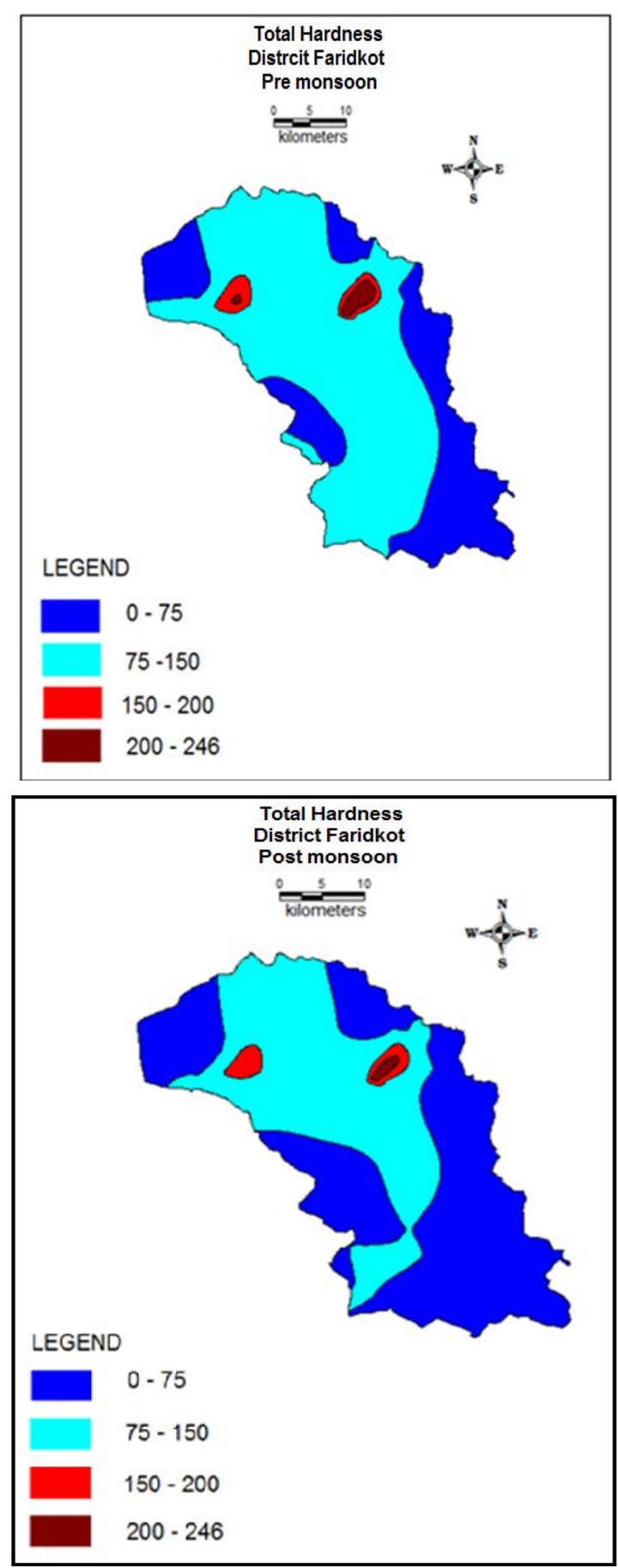

Figure 4: Distribution of $\mathrm{TH}$ as $\mathrm{CaCO}_{3}$ in the groundwater of Faridkot district 


\section{International Journal of Science and Research (IJSR) \\ ISSN (Online): 2319-7064}

Index Copernicus Value (2015): 78.96 | Impact Factor (2015): 6.391
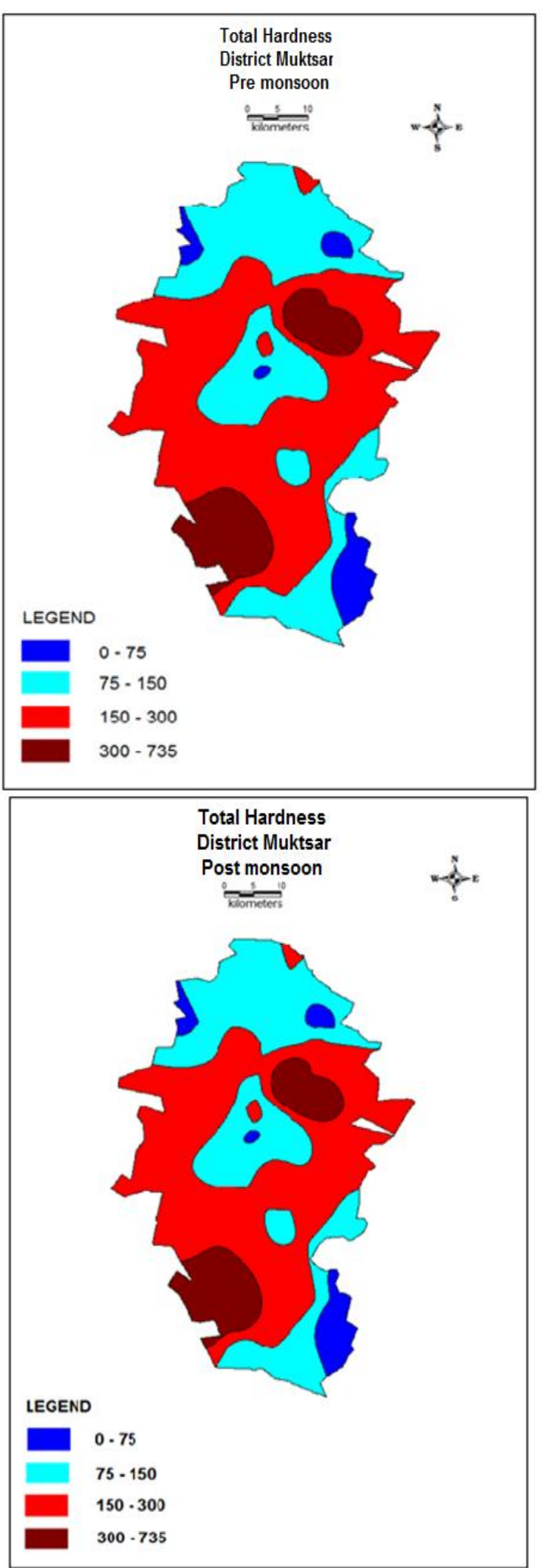

Figure 5: Distribution of $\mathrm{TH}$ as $\mathrm{CaCO}_{3}$ in the groundwater of Muktsar district

\section{Black Alkali Bicarbonate Hazard (Residual sodium carbonate index)}

Residual sodium carbonate (RSC) index of irrigation / soil water is used to indicate the alkalinity hazard of soil. High concentration of carbonate and bicarbonate in irrigation water may cause calcium and magnesium carbonate to precipitate in the soil. RSC index is used to find the suitability of water for irrigation mainly in claysoils which has highcation exchange capacity. When dissolved sodium in comparison to dissolved calcium and magnesium is high in water, clay soil swells or undergoes dispersion which drastically reduces its infiltration capacity.

Water with low $\mathrm{Ca}^{2+}(<2 \mathrm{meq} / \mathrm{l})$ and high amounts of carbonates result in specific toxicity symptoms. These include scorching and leaf burning at the early seedling development stage of crops. High bicarbonate also result in increase in $\mathrm{pH}$ of the soil rendering it to a condition known as Black Alkali Bicarbonate Hazard, which is caused by RSC or Residual alkalinityin water, has been computed by method devised by Richards (1954). The residual sodium carbonate (RSC) can be expressed as (where all ions are expressed in meq/l.):

$\operatorname{RSC}(\mathrm{meq} / \mathrm{l})=\left(\mathrm{CO}_{3}{ }^{2-}+\mathrm{HCO}_{3}{ }^{-}\right)-\left(\mathrm{Ca}^{2+}+\mathrm{Mg}^{2+}\right)$ $<1.25$ =Good; 1.25-2.5=Doubtful; $>2.5=$ Unsuitable for irrigation

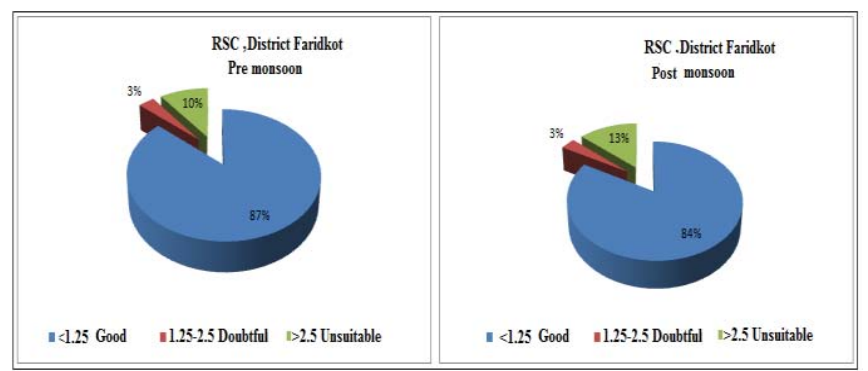

Figure 6: Suitability of groundwater for irrigation based on $\mathrm{RSC}$ in district Faridkot

In Faridkot during pre monsoon season, RSC ranged from $8.30 \mathrm{meq} / 1$ to $4.79 \mathrm{meq} / \mathrm{l}$ with average value of $-2.27 \mathrm{meq} / \mathrm{l}$ whereas in post monsoon, the concentration of RSC ion varied from $-7.31 \mathrm{meq} / 1$ to $7.62 \mathrm{meq} / \mathrm{l}$ with an average value of $-0.73 \mathrm{meq} / \mathrm{l}$ (Table 4 ). $3 \%$ samples in pre and post monsoon seasons fall in doubtful category and $10 \%$ samples in pre monsoon and $13 \%$ samples in post monsoon fall in unsuitable category (Fig. 6).

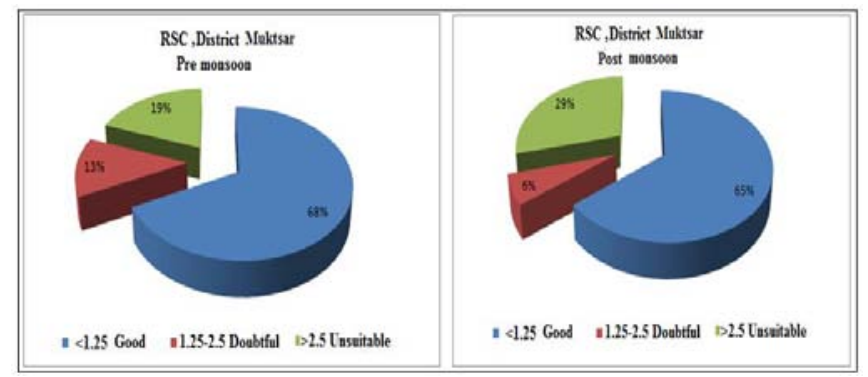

Figure 7: Suitability of groundwater for irrigation based on RSC in district Muktsar

In Muktsar during pre monsoon season, RSC ranged from $13.64 \mathrm{meq} / 1$ to $15.15 \mathrm{meq} / \mathrm{l}$ with average value of -1.59 meq/1 whereas in post monsoon, the concentration of RSC ion varied from $-12.94 \mathrm{meq} / 1$ to $18.13 \mathrm{meq} / \mathrm{l}$ with an average value of $0.44 \mathrm{meq} / 1$ (Table 5).13\% samples in pre monsoon and $6 \%$ samples in post monsoon season fall in doubtful category and $19 \%$ samples in pre monsoon and $29 \%$ samples in post monsoon fall in unsuitable category (Fig. 7).

\section{Volume 6 Issue 1, January 2017




\section{Conclusions and Recommendations}

The hydrochemical analysis reveals that the availability of good water in both the districts is limited and farmers have to resort to the use of saline groundwater and available canal water. Faridkot district which decade back used to be water logged now shows declining water table while Muktsar faces serious water logging conditions. In Faridkot district salinity is increasing making water unsuitable for irrigation whereas in case of Muktsar district water is unsuitable for irrigation in almost entire district and most of the area is water logged, as the groundwater is not used at all.From the above analysis, it is concluded that the groundwater in Faridkot and Muktsar districts is in general unsuitable for agricultural and irrigation purposes except for few locations. In Faridkot district the crops consuming less quantity of water may be grown in place of crop requiring more water in the over exploited block. Encouraging tolerant crops like Barley, Wheat, cotton, 'sunflower, so that groundwater of marginal quality can be used for irrigation.Conjunctive use of groundwater with canal water for irrigation is necessary to avoid further degradation and overexploitation of groundwater.

\section{References}

[1] Doll, P., Fiedler, K., and Zhang, J,(2009). Global-scale analysis of river flow alterations due to water " 20 withdrawals and reservoirs, Hydrology Earth Syst. Sci., 13, 2413-2432.

[2] FAO (1996). Food, agriculture, and food security: developments sincethe world food conference and prospects, World Food Summittechnical background document.13-17

[3] Subramanian V, Saxena K (1983) Hydrogeology of groundwater inDelhi region of India, Relation of water quality and quantity.In:Proceedings of the Hamberg symposium, IAHS publication no.146

[4] Mohtabullah,K.(1997).Water resources development and utilization in Pakistan: Potential and Challenges. Int Symposium on water for 21 century.17-19 June, Lahore 1-12

[5] UNWWAP (United Nations World Water Assessment Program),(2003).Water for people: Water for life, UN World Water Development Report, UNESCO, Paris, France, 576pp

[6] Singh,K., Hundal,H.S. and Singh,D. (2009). Geochemistry and assessment of hydrogeological process in groundwater in southern part of Bhatinda district of Punjab. Environment Earth Science, 5964(7):1823-1833

[7] Richards LA (1954). Diagnosis and improvement of saline alkali soils.US Department of Agriculture, Hand Book, 60:160

[8] Karnath ,K.R. (1989). Quality of groundwater assessment development and management. Tata McGraw-Hill, New Delhi, 217-275

[9] Mohan R, Singh AK, Tripathi JK, Chowdhary GC (2000). Hydrochemistryand quality assessment of groundwater in NainiIndustrial area, Allahabad district, Uttar Pradesh. J GeolSocInd,55:77-89

[10] Wilcox LV (1955) Classification and use of irrigation waters.USDA,Circular 969, Washington, DC, USA
[11] Sharma, P., Rishi, M., Thakur, T., (2014).Assessment of waterlogging and salinity in Muktsar district of southwest Punjab, Earth Science and Engineering, 7(1):202-212.

[12] Kumar, M., Kumari, K., Ramanathan, A. L., and Saxena, R., (2010).Comparative evaluation of Groundwater suitability for irrigation and drinking purposes in two intensively cultivated districts of Punjab,Environmental Geology,53(3):477-500

[13] Hayashi, M.(2004). Temperature-electrical conductivity relation of water for environmental monitoring andgeophysical data inversion.Environmental Monitoring and Assessment, 96, 119-128.

[14] Verma, V.K. ,Sharma, P.K.,Setia, R.K. (2007) .Ionic composition and hazards of poor quality waters for irrigation in southwestern part of Punjab.Hydrology journal,3-4(30):1-11 